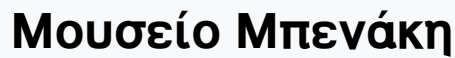

A Singular Antiquity: Archaeology and Hellenic Identity in Twentieth-Century Greece

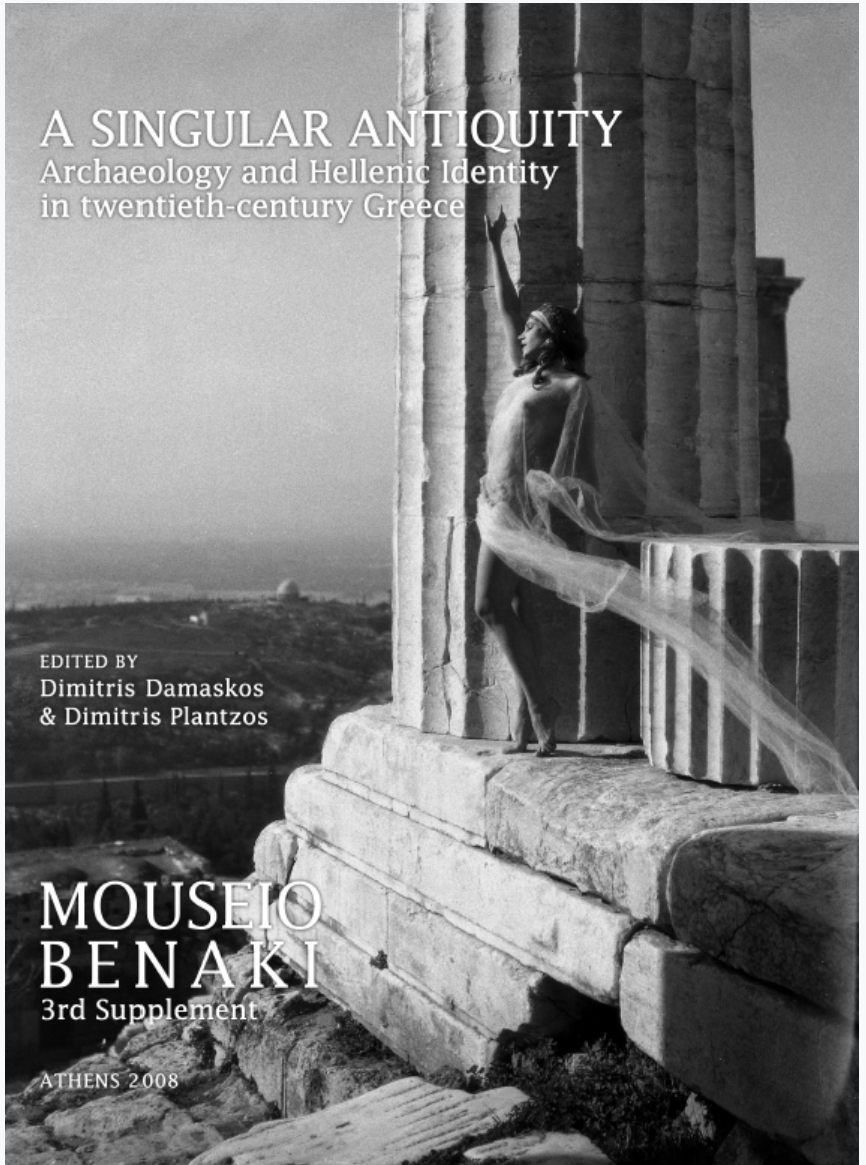

Archaeology and Hellenic identity, 1896-2004: the frustrated vision

Dimitris Plantzos

doi: $10.12681 /$ benaki.17969

Copyright $\odot$ 2018, Dimitris Plantzos

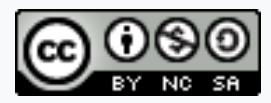

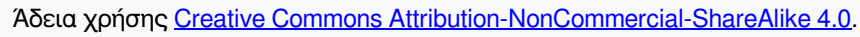

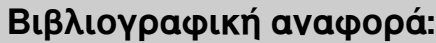

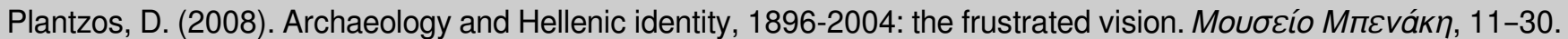
https://doi.org/10.12681/benaki.17969 
INTRODUCTION 


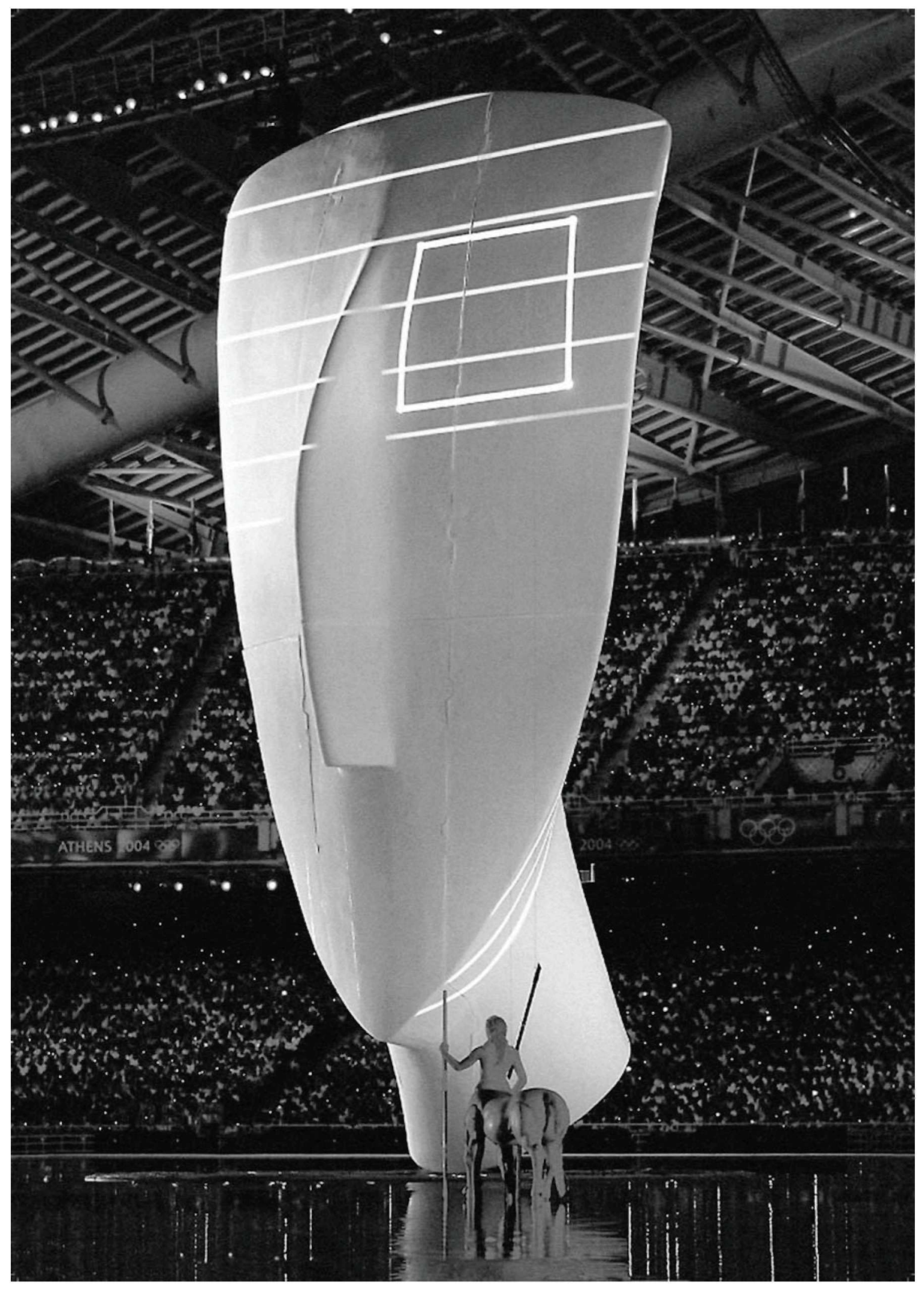

Fig. 1. Opening ceremony of the Olympic Games in Athens: a Cycladic head emerges from the sea (@Athens 2004; courtesy Michalis Toubis SA). 


\section{Archaeology and Hellenic identity, 1896-2004: the frustrated vision}

'In the modern world the past is a commodity of mixed value'. J. Boardman, The Archaeology of Nostalgia (2002) 7.

ON THE EVENING OF 13 August 2004, a gigantic Cycladic head emerged from the waters of an artificial lake built in the heart of the Olympic Stadium in Athens (fig. 1). The city was hosting the twenty-eighth Olympic Games of the modern era, and this was to be the centrepiece of the opening ceremony. This epiphany of sorts was followed by a state-of-the-art, hi-tech spectacle combining men and machines, schemes and ideas, all masterfully visualized and staged by choreographer Dimitris Papaioannou. ${ }^{1}$ The Cycladic head cracked open, Zeus-like, to produce a colossal kouros, which then gave way to a Classical torso (fig. 2). A procession ensued, presenting life-like statuary and Leitmotiv ideas, references to familiar images, a celebration of a culture through the spectre of its own beauty (figs 3-4). A 'precession of simulacra', in short, to remember Jean Baudrillard, ${ }^{2}$ whereby Greek culture was represented through its art, where idea was subjugated to form, where history as experience was paraded as Motivgeschichte.

Papaioannou's scheme was brilliant, striking just the right notes for the occasion: emphasis on continuity (though with a certain antique bias), a celebration of the all-time-classic Greek ideal (albeit in its consummation through art), an allusion to some of the eternal Greek values - such as democracy, the theatre, or Christian faith - all suitably packaged for worldwide broadcast and PG audiences throughout (with the exception of nudity, certainly, which seems mandatory when it comes to things Greek). A confirmation of Hellenic identity overall, through a rehearsal of Greek history based on tangible archaeological evidence and its aesthetic appeal, and moreover a reaffirmation of this culture's connection - past, present, eternal - with the land (and the sea, needless to add) that gave birth to the peerless Hellenic spirit.

Remarkable attention was paid to historical accuracy throughout: the Cycladic head of the Olympic show, for example, was a hyper-blown up copy of an actual ancient artefact, one of the most treasured masterpieces exhibited at the Museum of Cycladic Art in Athens. It was readily recognizable to anyone even remotely familiar with the 39 $\mathrm{cm}$ tall figurine, even though the replica of its head alone in the stadium stood 17 metres high. ${ }^{3}$ The procession of statuary was crowded with effigies of well-known kouroi and korae, Classical grave stelae, a replica of the Parthenon, and so on, all the way down to Byzantine frescoes and mosaics, Greek folk art and shadow puppet theatre.

Every motif, each portentous symbol, had its place: Cycladic art at the forefront, to be sure, since, from as far back as the last decades of the nineteenth century, it has been being used as the first milestone in the long and fascinating saga of Greek ('Hellenic') Culture, as this has been constructed by the modern Greek state. In this continuum, 'Cycladic' plays counterpart to 'Modern', by standing as the far bookend in a sequence of arts, ideas, and the men who expressed the latter through the former. This idea of continuity in itself, from Cycladic to Classical art, then moving through Byzantium to modern Greece, was essential to the construction of Greek national identity in the late nineteenth and throughout the twentieth century, and remains in use with no signs of subsiding. Greek culture (as monitored through its expression in art) and history (as evidenced by its manifestation through culture) are emphatically poised to begin in the depths of prehistory and 


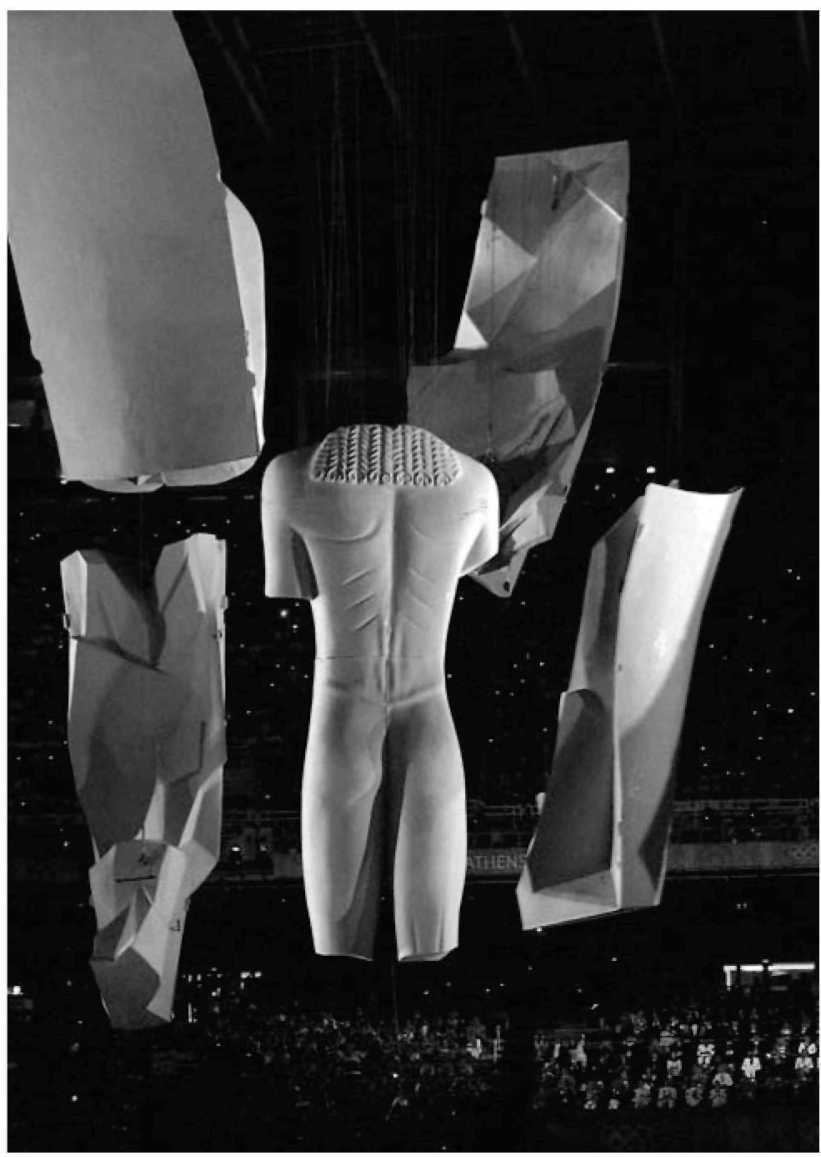

Fig. 2. A kouros coming into view at the opening ceremony of the Athens Olympics (CShaun Sullivan).

culminate in the here and now, on the much celebrated threshold of the third millennium $\mathrm{AD}$. Thus, in order to commemorate its hosting of the Olympic Games, Greece (that is Athens) chose to dress up and, in shamelessly selfworshipping mood, admire her image in the mirror: ${ }^{4}$ that is Greece's own Hellenic view of her own Hellenic (mostly ancient, mostly Athenian) art. ${ }^{5}$

Notes from oblivion

The scheme proposed by the Olympic procession is, needless to say, an old one, which has been tried and tested by Greek and Western scholars to represent, by way of explanation, historical developments in ancient, medieval, and modern Greece, a reading as good as any other - contrary to the opinion of many of its critics - and one that has arguably

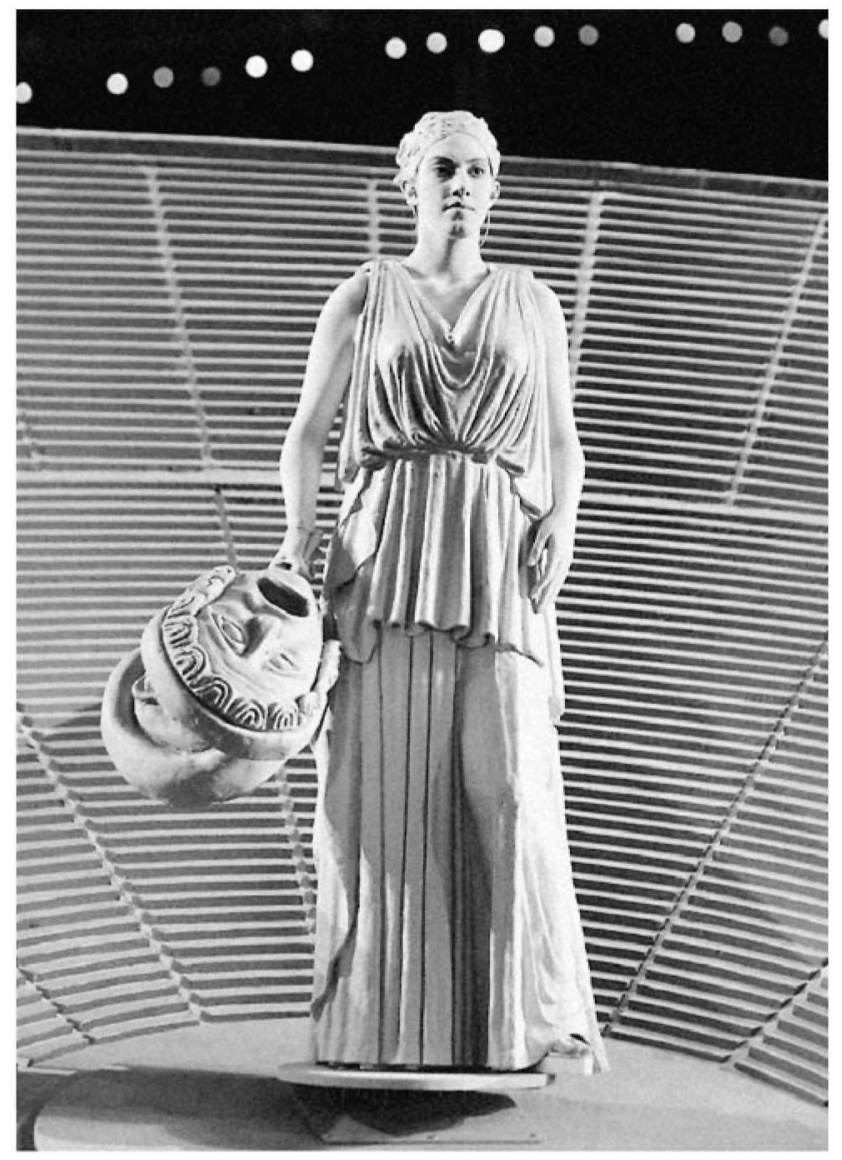

Fig. 3. A reference to Greek theatre at the Athens Olympics (CAthens 2004; courtesy Michalis Toubis SA).

proved much more successful than some might have done. ${ }^{6}$ Yet it is a representation that the ancient Greeks themselves would have found difficult to come to terms with: they, for one, would have been mystified by the pristine whiteness of their paraded statuary, by the strong violation of proportion, context and function. And as for the ancient Cycladic islanders themselves, they would very likely find the grossly inflated head, severed from the body of one of the smallscale (presumably) human effigies so familiar to them, positively grotesque. Be that as it may, we-modern Greeks and Westerners - have learned to recognize ourselves in Greek art, have been taught to reflect on the classical past as our own, and have been instructed to see Cycladic art as beautiful, inspiring, and as a forerunner to our own aesthetic values of simplicity, sophistication, and abstraction. Since the days of Winckelmann, Greek art has been made, through an emotive leap of faith, to function as an emblem of the to- 


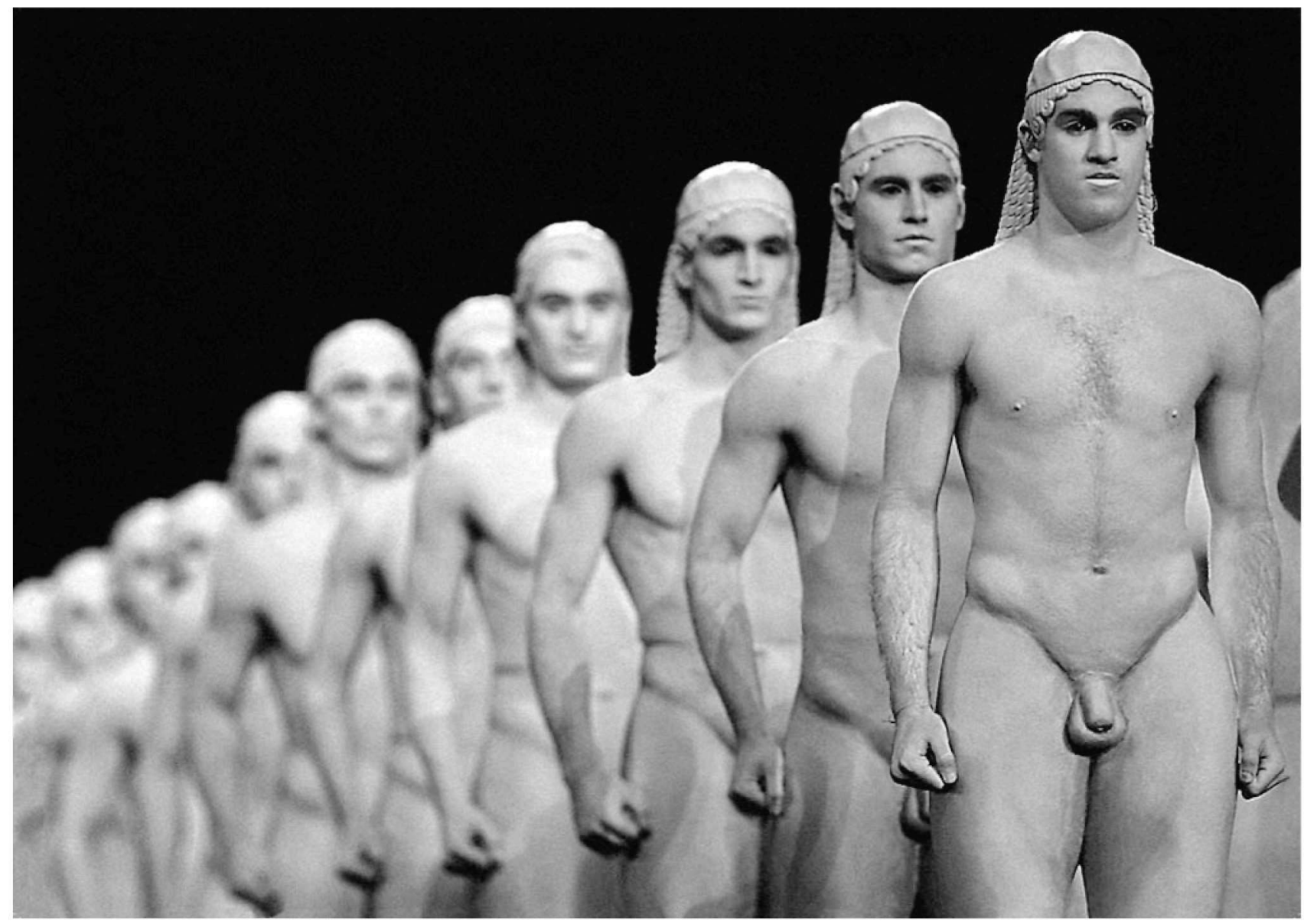

Fig. 4. A procession of live 'statuary' at the Athens Olympics (CAthens 2004; courtesy Michalis Toubis SA).

tality of Greek culture, ${ }^{7}$ and this has facilitated its use, as the logo, so to speak, for Hellenic culture in total, in the familiar process of (self-)colonizing one's past in order to promote one's rights to the present. ${ }^{8}$ These images are vital therefore: ostensibly, they are broadcast worldwide even though their primary function is introverted, aiming to touch the nation's collective imagination so as to 'give the nationalist struggle something to revive and admire'.?

The conviction that life speaks through art permeates Greek archaeology, surreptitiously having acquired the status of a self-evident truth. A good example is the Benaki Museum itself, the gracious host of both this volume and the original conference: its most recent guidebook maintains that, starting from the Prehistoric room (where a Cycladic figurine may be seen along with other third-millennium artefacts), 'the visitor will follow, step by step, the historical development of Hellenism as it unfolds through the millennia'. ${ }^{10}$ Speaking as it does of an 'exciting journey' and a 'true epic' this idiosyncratic statement prefigures the Olympic procession by several years, offering at the same time an eloquent description of the way modern Greece undertakes its own archaeology, as an exercise - often painstaking but ultimately rewarding - in deep soul-searching and courageous self-cognition. And who could be better qualified to do this than the Benaki Museum, the Hellenic museum par excellence, which - in its own words - strives to illustrate 'the character of the Greek world through a spectacular historical panorama'?11 This is the scheme that Papaioannou chose to serve with his Olympic procession, just as the Benaki Museum's exhibition starts with Cycladic art and culminates with modern Greek poetry. ${ }^{12}$ Both stand as eloquent metaphors for the way Greeks have striven to construct their collective identity through a singular perception of a/their historical past; and, judging by their 
success with their respective audiences, this is still an entirely valid reading. We are reminded of Christian Zervos, the Greek-born art critic and influential patron of modernists such as Picasso, who, in his efforts back in the thirties to promote the idea of a culturally continuous and intellectually luminous Hellas, wondered whether 'a Cycladic figurine, a vase or a bronze artefact of the Geometric period, a statue or a pot of the Archaic period, do [...] not already contain the essential elements of the style of the Parthenon'. ${ }^{13}$ His anachronistic understanding of Greek archaeology strikes a note of magnificent absurdity in backdating the notion of Hellenism to a time prior to its actual presence. At the same time, it offers a splendid illustration of the ideological premise underlying the modern narrative of Greek archaeology, expressed in its atemporal - and heavily aestheticized - view of ancient Greek culture.

Such readings, like the linear arrangement of the Olympic procession, serve as vivid reminders of the task undertaken by modern historiography: to produce a straightforward, authoritative, and objective account of the past, inspired by the scientific values of rational assessment and empirical reasoning; in short, a safe, sane, and consensual version of history suitable for a wide, largely uninformed but extremely demanding audience. In the case of Greece, it reminds us that archaeology has been conscripted into establishing a new cultural and political identity for a new nation-state, anxious to broadcast its own singular antiquity.

\section{Custodians in Neverland}

The discovery and preservation of antiquities in nineteenth-century Greece was motivated by a number of objectives:

'[T]o link the young Greek state and the neo-Hellenes with the Classical Greek antiquity of which they, since they spoke the same tongue and inhabited the same land, were the direct heirs and agents; to defend the young nation and state against those who wished its demise; and to put an end to, or at least to reduce, the destruction of antiquities in liberated Greece by its own inhabitants, be they peasants or smugglers, as well as the foreign archaeophiles and antiques traders. ${ }^{.14}$

Since the passage quoted here was written in 1987 , we may assume that its author believed Greek archaeology to have served these ends in the intervening one hundred years or so, though it is difficult to imagine a studious body of under-paid civil servants 'defending the nation', eager as they may have been to do so (and many certainly were). The passage is of course revealing as to the ways the Greeks themselves perceive their link to classical antiquity and the political-cum-national role they attribute to archaeology. It is also revealing in that, although it lists three 'objectives', only one - counted last and presumably least - is, strictly speaking, related to an archaeologist's actual work: rescuing antiquities from the hands of looters, a task also invested with patriotic significance.

What this text fails to point out is that - from the very beginning of the modern state - Greek archaeologists undertook the task of constructing Greece as a geographical as well as an ideological topos, a heterotopia in the Foucauldian sense. ${ }^{15}$ Creating 'a space of illusion that exposes every real space', heterotopias are deployed as systems of institutions, discourses and ideologies in order to act as 'counter-sites' on which real sites, active within the particular culture, are colonized by this 'kind of effectively enacted utopia[s]. ${ }^{16}$ Greece has been described as such a Foucauldian heterotopia by Artemis Leontis: ${ }^{17}$ 'a space set apart precisely because it contains classical ruins', ${ }^{18}$ a site expropriated by the colonialist imagination of the West, and eventually recreated, and thus self-colonized, by modern Greek writers, who claim their own (hereditary?) intellectual rights to a magnificent past. Indeed, archaeologists in Greece were inspired by some of the country's leading intellectuals in their efforts to enhance their nation's intellectual singularity, based on the promotion of the classical past (the material remains of which had been entrusted to their safekeeping), in the belief that the ruins could bridge the gap between past and present, in a physical as well as a synaesthetic way.

The heterotopia of Hellas, which remains active in modern Greece, and appropriates the country's realities, strategies and imaginings, has proved to be endowed with the formidable intertwining of enjoyment and oppression that forms the backbone and the interminable energysource of nationalism'. ${ }^{19}$ Classical ruins, their protection, enhancement, even veneration, and the way Greek archaeology has gone about the recreation of Greek landscape as a way of reappraising the past, came therefore to perform, much more than a visual role (accepting the past as an 
aesthetic ideal), a fundamentally political one. As Yannis Hamilakis put it in his own exploration of the heterotopia scheme: 'the material landmarks of this heterotopia operate not simply as the iconography of the national dream (however important that role is), but also as the essential (in both senses of the word), physical, natural, and real, and thus beyond any dispute, proof of the continuity of the nation, a key device for its naturalization. ${ }^{20}$

Constructing the heterotopia of Hellas was a long process; inspired by Bavarian Neoclassicism, Greek archaeologists worked to 'purify' national monuments - meaning strictly those with a classical pedigree - wishing to emphasize 'the national, emblematic character required by Greeks as the foundation of their national identity'. ${ }^{21}$ The 'purification' campaign started from - where else? - the Athenian Acropolis which had to be restored back to its glory days. The demolition, in 1875, of the Frankish Tower that stood by the Propylaea was one such act of 'purification', targeting a monument that was regarded as emblematic of a foreign occupation that had to be shown - like the Roman and the Ottoman - not to have left anything behind that was worthy of note, apart, of course, from those elements which had been 'rehabilitated' into Hellenism through a rigorous process of cultural appropriation. Though it met with strong protests from historians - mostly foreign, and notably the French who themselves regarded the Tower as their own national treasure ${ }^{22}$ - the demolition of the monument was emphatically supported by the Archaeological Society who stressed the need to render national monuments 'pure and unsullied by anything foreign' ${ }^{23}$

Behind the ideological premise - so dominant in Greek archaeology - of modern Greece's moral debt to its classical past, lay a much more pragmatic approach: the idea that the country's landscape, dotted by antique sites and monuments, could be exploited to the state's economic advantage. The idea that Westerners came to Greece expecting to find the sites in good order had been a preoccupation of Greek archaeology since its early days. As a matter of fact, it was the example of the Grand Tourists and Philhellenes of the previous centuries which had encouraged the Greeks to appreciate the monuments of their land in the first place. Mass tourism, a phenomenon which emerged in Europe and the Western world in general between the wars, was seen by the Greek authorities as a viable way of increasing national revenue. A first tour- ist bureau founded in 1914 was succeeded in 1929 by the Greek National Tourism Organization (EOT), a central priority of which became the conservation and enhancement of archaeological sites and monuments for the purpose of attracting and entertaining foreign tourists. In the thirties several sites in Athens and the rest of the country were 'cleared up' or 'made decent' by removing later buildings (including churches) and manned with tour guides for the sake of tourists. In 1934 Georgios Oikonomos, in his joint capacities as Secretary of the Archaeological Society at Athens and Director of Antiquities at the Ministry of Education, called for the reinforcement of the Archaeological Service in the interest of public finances. He argued: 'It is fundamentally clear that in our efforts to establish our country as one of the most important destinations for foreign tourism, we are, at least for the time being, obliged to support every aspect of this truly national project of ours relating to the state of our archaeology and our monuments. ${ }^{24}$

An extensive restoration project was launched, primarily targeting ancient theatres, to serve as venues for the revival of ancient drama. The Herod Atticus Theatre in Athens (an odeion of the Roman period) was being used for such performances - 'bound to attract the attention and the interest of foreigners ${ }^{25}$ - long before it was massively reconstructed in the fifties. ${ }^{26}$ Soon enough, the Greek Tourism Organization was proposing annual revivals of ancient drama for dollar-paying tourists; and archaeologists, philologists and theatre companies were happy to oblige.

It was thus that the international imagery for Classical Greece was created: researched, ostentatious, and thoroughly modern. More to the point, archaeologists became the arch censors of national aesthetics, stipulating what was to be allowed in modern Greek culture, based on an improvised hierarchical system of values prioritizing the (perceived) integrity of classical aesthetics. ${ }^{27}$ Canonized in the mind of archaeologists and the Greek people at large, antiquities have become, even in recent years, the recipients of quasi-religious veneration that might embarrass an otherwise typically Western, secular state (even one, like Greece, marked by some decidedly un-Western, and rather disconcerting, peculiarities): Greek authorities have recently introduced a ban on posing for pictures in front of ancient monuments in museums and archaeological sites 'as a show of veneration' to them, usually enforced by enraged stewards against flabbergasted (and otherwise most 
welcome) tourists seeking, in universal tourist etiquette nowadays (obnoxious as it may be), to immortalize themselves in front of a classical statue or a ruin. ${ }^{28}$

On many an occasion from the early years of the Greek state, archaeologists working for the Ministry of Culture, the University, or both, were allowed to intervene in situations involving contemporary culture - from events taking place in or near archaeological sites to displays of modern or non-Greek art - and have the last say in the matter. Using the powers of persuasion they draw from a portentous past which they profess to represent, as well as the disciplinary powers invested in them by the state, Greek archaeologists continue to produce and recycle aesthetic value for the sake of the nation. Theirs was the 'archaeologically correct' imagery paraded in the opening ceremony of the 2004 Olympics. Theirs is the heterotopic landscape, duly 'cleansed' and appropriately 'archaeological', crafted across Greece through doctrine, intervention and censorship.

A recent clash, rendering the Acropolis once again a site of conflict, should suffice to show the way Greek archaeology - state or public - views its own and the country's relationship to the classical past. The decision taken by the Central Archaeological Council to approve the de-classification of two previously listed buildings in the vicinity of the new Acropolis Museum in central Athens has stirred a wave of public controversy. The two buildings, one a rare example of the way modern Greek architecture adopted the achievements of art-deco architecture and the other a Neoclassical building with strong overtones of the Gothic Revival, are part of an urban street preserving valuable examples of private houses of the early twentieth century. ${ }^{29}$ The decision to tear down the two buildings rested on the 'needs' of the new museum for an uninterrupted view of the Acropolis, in order to establish a 'visual conversation' with the monument. ${ }^{30} \mathrm{~A}$ massive building of (questionable by some $)^{31}$ international architectural merit, the new museum, designed by Bernard Tschumi, is intended to enhance Greece's international standing as a host of modern architecture as well as its prospects of seeing the eventual return of the Elgin marbles - a national project indeed.

The inherent visualism of Greek archaeology, deeply embedded in its empiricist tradition, a tendency that has been elevated to the status of the discipline's primary tool of conviction, cultivates a cultural bias towards the visual ('what you see is what you get'), an attitude that is fundamentally ideological..$^{32}$ In the case of the Acropolis museum, the modern has to be given uninterrupted visual access to the ancient, a co-existence that has to be selfevident and eternally present. No intermediaries can be allowed, no interruptions, especially if they are not part of the linear succession from antiquity to the present; most especially if they are unwelcome reminders of foreign interventions unworthy of our merit, as in the case of the Frankish Tower on the Acropolis or the art-deco house classified as a listed building in the seventies by the same authorities which now want to demolish it. Archaeology is thus used to deploy an improvised visual rhetoric, satisfying its public's (as well as its own) idolatrous tendencies in order to shift the discourse regarding the past towards the pictorial and the aesthetic. Besides being a filial duty towards an imposing past, this heterotopic approach to the development of urban landscapes in modern Greece has been understood by Greeks as a way of meeting outsiders' expectations of them and a way of achieving international acceptance and financial benefits. In one of the countless texts urging the state to get rid of the two 'unimportant' listed buildings for the sake of the 'common good' written by various 'public intellectuals' catering primarily for the press, we read that 'no [foreign] visitor will come to Athens in order to see an art-deco façade, though many will come for the Acropolis Museum, provided we promote it appropriately. ${ }^{33}$ Several decades on, the best part of a century, Greek archaeology - in the wider sense of the term - struggles to illustrate the nation's importance through visual reminders of its antiquity, while at the same time striving to satisfy the needs of its visitors in return for their material or moral support. True enough, the fate of the two houses was apparently sealed when it was realized that, although the Parthenon would be clearly visible from the new museum's galleries (one of which is to remain empty until such time as the Elgin marbles are returned to Greece), the backs of the two buildings obstruct the view to the 'mother rock' from the landing which is to become the museum's cafeteria. ${ }^{34}$

Archaeology thus provides the theatre and the props for a strategically placed production of modern Greece as a continuation of Hellas. The ideological and aesthetic components of this re-enactment will be discussed below. First, we need to consider the central premise of this enterprise, a 'passion play' as it has been called, ${ }^{35}$ where what is at stake is Greece's capacity for self-determination and - more importantly - just who, within the state itself, has 
the right to set the rules of this process. Needless to say, although this endeavour, one that has led to violent and as yet unresolved conflict in Greek society, affects Greece's outlook on the future, it is primarily concerned with its definitive reading of the past.

\section{The Greekness of our discontent}

The scheme employed at the Athens Olympic ceremony was a long time in the making: as early as the second half of the nineteenth century Greek historians sought to furnish Greece with a national history worthy of a modern European state. ${ }^{36}$ The historian and folklorist Spyridon Zambelios (c. 1813-1881) was the first Greek scholar officially to speak of the national character of the Greek people, a character evident throughout its three-thousand-year long history. His references to Greek national consciousness, his emotive invocations of a throbbing national heart he could detect in Byzantium as well as in classical antiquity, echo the rhetoric of German Romantics such as the philosopher Johann Georg Hamann and his disciple Johann Gottfried von Herder, as well as the eighteenth-century Neapolitan critic of the Enlightenment Giambattista Vico, who may have been an inspiration to them. ${ }^{37} \mathrm{Zam}-$ belios assumed the task of constructing a coherent timeline for Greek history, capable of withstanding external (i.e. European) scrutiny. His effervescent rhetoric builds on Romantic rapture, though tacitly claiming this as a purely Greek trait. In one of his many texts on language, published in 1856, Zambelios states, on behalf of his nation, that 'we live in the present, but have been born many centuries ago, and it is the air of those centuries that we now breathe. Our very idiosyncrasies, our fantasies, and our preposterous aspirations bear witness to us being les enfants gâtés de l'histoire'. ${ }^{38}$

Greek history soon became a national cause - a legitimizing force both at home and abroad. The ancient legacy was now being confirmed by modern science since Romantic Philhellenism, to which the new state owed its independence, was in irrevocable decline. Konstantinos Paparrigopoulos, Professor of History at the University of Athens, in a remarkable effort to hellenize Greek history, produced a new synthesis, uniting ancient and medieval (Byzantine) Greece with the present. In his History of the Hellenic Nation, which appeared in many editions and revisions in the period 1860-1876, Paparrigopoulos constructed a tripartite 'national-time' scheme for modern Greece as a European nation-state. ${ }^{39}$ Thus, Hellenism became the protagonist in the continuum of the Greek narrative; what for the modern historian could (and would) be seen as a revival - following a murky and inglorious medieval intermission - had to be shown in the Greek nationalist reading to be a survival, even if some of the interim stages had to be left to one's imagination. The sentiment underlying this, and many such historiographical endeavours, was an ambivalence towards the West - contempt for its intellectual inferiority and its many shortcomings, as well as an intense anxiety to be accepted, on equal terms, in its circles. Greek folk studies, initiated in the 1880 s by Nikolaos Politis, who strongly believed that local customs and traditions preserved the essence of Hellenism, also benefited from an inherent anti-Western tone: a frank return to tradition, Politis was arguing in $1883,{ }^{40}$ would save Greece from losing its soul to the seductive influences of the West.

These fiercely conflicting views marked most of the twentieth century, affecting readings of the Greek (classical) past and (modern) present. In 1903 the Greek poet and essayist Periklis Giannopoulos (1869-1910) published his Greek Line and Colour, urging his compatriots to reunite with the spirit of ancestral Hellenism and overthrow the 'tyranny of the West' through a thorough reappraisal of the national Greek values. According to Giannopoulos, these values had been invested in the Greeks by their own earth, the Greek land that created its people 'in her own image and likeness'. Inspired by Darwinian and other evolutionist theories of culture developed in Europe, mostly Germany, this vein of determinist reasoning has had a lasting effect on Greek perceptions of history, geography and race. ${ }^{41}$ Biological idiosyncrasies and climatic conditions were (and often still are) seen as determining factors for culture, and Greek art - understood as a reflection of the contours and colours of the Greek landscape - was perceived as an expression of this interaction between man and his land. The chief idea expressed by Giannopoulos in his polemical essay is that the Greek soil is the cradle of Greek aesthetics, and that Greek art was the product of the dialogue between the Greeks and their own environment. The nub of his critique was his fierce anti-Occidentalism, a sentiment he shared with many of the young thinkers and activists of his day. Greek cultural identity had to be 
regained, as a bulwark against the deceptive forces of the West and the complacency of the East, which had left a deep imprint on Greek soil, with an Ottoman occupation that had lasted four hundred years too long. Giannopoulos and his fellow radicals could not hide their frustration at the westernization of their homeland: in the process of becoming a bona fide Western state, Greece was abandoning its Hellenic destiny.

At about the same time, Greek archaeologist Christos Tsountas (1857-1934) took advantage of Heinrich Schliemann's and his own discoveries at Mycenae and Paparrigopoulos' synthesis, in order to talk about the existence of a timeless 'Greek spirit', permeating Greek history from prehistory to the present, in an effort to claim that Greece really was the cradle of European civilization. ${ }^{42}$ Gradually, Greece was constructing its solidly Hellenic prehistory, enabling its scholars to claim that all things worthy of our attention - from the depths of the prehistoric past to the post-Byzantine present - had been produced by the spirit of the land and the genius of the race. Anything else was what Greece's multifarious invaders - Romans, Goths, Franks, Turks - had left behind and merited only contemptuous indifference.

Following a humiliating defeat in the war against Turkey in 1897 and the Catastrophe that followed the invasion of Turkish Asia Minor by Greek troops in 19211922, the Greeks finally realized that their nation was to remain confined within the territory held by their state. Thus, the nationalist Megali Idea ('Great Idea'), a highly romanticized claim for a 'Greater Greece', a sovereign state that would stretch over every territory inhabited by $\mathrm{Hel}$ lenes, ${ }^{43}$ was finally abandoned more than sixty years after its conception.

Disenchanted by the unceremonious end of the Greek imperialist dream, ${ }^{44}$ a younger generation of intellectuals who emerged in the country's cultural life around 1930 (who became known as the 'generation of the thirties'), 45 displayed a markedly more introvert attitude. Their influence on Greek culture was strongly felt for the decades to come and many aspects of their legacy remain evident to the present day. These active essayists, critics, novelists and poets devoted their energy to a new central concept for Greek identity, what they called hellenikoteta ('Greekness') or Hellenicity. Hellenicity referred to the intrinsic qualities of the Greek psyche which had survived, often undetected, through antiquity and Byzantium, to the present day. Thanks to their middle- or upper-middle class upbringing and studies abroad (in Western Europe, mostly Germany), the members of the generation of the thirties understood well the challenges modernity - modernization even - posed for their country. While striving to reunite modern Greece with its long-lost Hellenic psyche, they endeavoured to promote Greek culture in the West, as a reminder to the European Occident of its cultural debt to the Greek Orient. On the surface at least, one might think that their attempts were generally successful: two of the group's most prominent poets, Seferis and Elytis, became Greece's only Nobel-laureate poets to date, in 1963 and 1979 respectively. Evidently, their Greekness had touched some European chords. ${ }^{46}$

Intriguingly, Greek intellectuals in the thirties seemed to believe that the 'new humanism' they were after could be further inspired by the environmental-determinist views promoted by Giannopoulos at the beginning of the century, views which they duly revived, along with - to a certain extent - his reckless rhetoric which remains popular to the present day. ${ }^{47} \mathrm{~A}$ new sort of hellenocentric radicalism made it obligatory for Greek intellectuals or artists to declare their fascination with the landscapes of Attica, the colours of Greek nature and certainly the Aegean and its islands: this becomes the cradle and residence of Hellenism, to which all the characteristics which shape Hellenicity are to be credited. ${ }^{48}$ Thus, the Greek quest for a national identity veered towards aesthetics. ${ }^{49}$

The Metaxas dictatorship in 1936 pushed for a further ideological swing. Metaxas wrested Hellenicity from the hands of his liberal or communist rivals (effectively silencing the latter through exile, imprisonment, or worse). From then on, the Greek Left and the Greek Right turned Hellenicity into a site of conflict, in a landscape of ideological intolerance, which showed no signs of subsiding in the bitter post-civil war years of the fifties and the sixties. ${ }^{50}$ Attacked from the right, liberal intellectuals now had to prove their patriotism by elaborating on stereotypes about the Greek soul and the eternal spirit of Greek culture. Meanwhile, many communist intellectuals, originally indifferent, if not positively hostile to the notion of Hellenicity, were finally forced to subscribe to it, lest they be accused of 'cosmopolitanism'. ${ }^{51}$ Though apparently centred on the past, the issue under debate was presentday relations with Europe; for the liberals 'Greekness' could be perceived within a European framework, and 
was thus a bona fide ingredient of modernity. For Greek conservatives, on the other hand, modernity was certainly anti-Hellenic. Inevitably, the rift caused was vast, and its impact is still felt in present-day Greece, not to mention the frequent invocation of nationalist rhetoric (with the appropriate emphasis on the amalgam of Greek heritage and Orthodox tradition) by many a self-appointed spokesman of the so-called Greek radical Right. Hellenocentric history, sterile archaeolatry, and frustrated anti-Western rhetoric remain, to the present day, the vital elements of the intellectual ancestry of every conservative in the country, with the Metaxas regime still providing both the ideological stimulant and the visual back-up for such expressions of patriotism.

It was in this cultural and political environment that Greek history, viewed through art, came to be seen as a single entity. Greek Modernism, represented by the intellectuals of the generation of the thirties or internationally renowned personalities like Christian Zervos mentioned above, promoted ideas on the singular essence of Hellenic art - Prehistoric to Byzantine. Greek painters in particular, heavily influenced by the discussion on Hellenicity in the thirties and the forties, turned to the past, inspired (or claiming to have been inspired) by ancient and medieval Greek art, in an effort to establish continuity and thrive on it. Most of these painters also designed for the stage, including performances of ancient drama: Yannis Tsarouchis, Yannis Moralis, Nikos Nikolaou, and Nikos Hadjikyriakos-Ghika became the champions of Hellenicity in Greek painting, combining their cosmopolitan outlook with their idiosyncratic approaches to the Hellenic (ancient, modern, timeless). ${ }^{52} \mathrm{~A}$ 'metaphysics of Greek landscape ${ }^{\prime 53}$ was thus constructed in art and literature, based on the ideals of an autochthonous Hellenicity and the perennial historical presence of Hellenism. ${ }^{54}$ Owing to the highly aestheticized rhetoric of these readings, archaeology - which was ex officio the provider of the masternarrative which served as the backbone of Hellenic history (namely ancient Greek and Byzantine art) was encouraged to adopt a similar approach both to the past and its own mission.

Strengthened by the 1936 coup, the Greek Right used Hellenicity as a patriotic index of sorts, in order to silence its political opponents, and to restrict intellectual contacts abroad. This was an anti-modern and anti-Western, xenophobic reading of Hellenicity, susceptible to state control.
Konstantinos Tsatsos, a self-styled 'Platonic' philosopher and politician with some presence in Greek politics before and after the 1967 dictatorship, produced numerous essays in which he is concerned with Hellenic creativity. He despises any sign of Modernism in literature and art 'because it excludes Hellenicity'. For him, Hellenicity is a prerequisite of authenticity: 'I don't need authenticity in order to have a Hellenic work; I want Hellenicity so that the work may be authentic'. ${ }^{55}$ As it happened, Tsatsos became (reluctantly?) the protagonist in a farcical episode in Greek cultural politics, involving the Liberal Left, the Right, and control over Hellenic antiquity and tradition. On 29 August 1959, a performance of Aristophanes' The Birds by the Art Theatre Company at the newly restored open-air Herod Atticus Theatre was interrupted by angry spectators, when a Byzantine psalm was interpolated in the play's sacrifice scene. The show had been directed by Karolos Koun, Greece's leading avant-garde director at the time, who attempted, with considerable success, to link his work with folk tradition and antiquity - very much in the fashion of the generation of thirties. His collaborators in The Birds included the painter Yannis Tsarouchis and the composer Manos Hadjidakis, all three united by a common vision of antiquity, folklore and contemporary culture. Tsatsos, then Minister of the Interior for a radical right-wing government, personally ordered that the three remaining performances be cancelled, on the grounds that the performance 'distorted the meaning of the classical text [and] insulted the religious sentiment of the people'..$^{56}$ Clearly, Hellenicity was too important to be left in the hands of irresponsible intellectuals.

1959 was (yet another) crucial year in Greek politics, when the right-wing National Radical Union party, under the leadership of Konstantinos Karamanlis, was in government. However, in the elections of the previous year, the United Democratic Left had emerged as the official opposition and was severely attacking the government on its handling of the Cyprus issue and the Zurich talks early that year. As Richard Clogg puts it: 'Karamanlis came under fire from the opposition for betraying the cause of Hellenism in the interests of NATO and the Americans'. ${ }^{7}$ Evidently, Tsatsos and the Greek Right had their own views on Hellenism and the way its interests should be defended, at least domestically. Following the termination of the seven-year military dictatorship in 1974, Karamanlis was elected Prime Minister and Tsatsos President of the 
Republic. While no overt references to their ideas were included in the 2004 Olympic Ceremony, Hadjidakis and Tsarouchis were right there in the forefront of things, the former thanks to the use of his dreamy music, and the latter as a not-so-distant inspiration behind many of the costumes or the staged scenes (particularly the navy bands parading by the seafront). The spirit of the generation of the thirties lives on, one might assume, though only in its most conservative, intellectually sterile mutations, calling for repetitive invocations of the past as a mechanistic measure against the discontents of the present. ${ }^{58}$ As Alexis Dimaras assessed in 1983, we ended up propagating an 'official Hellenicity', enforced by the state educational system through a regime of fear: fear that, through a crack in the system, 'the real face of modern Greece might be revealed' or that the character of this official Hellenicity may get tampered with. ${ }^{59}$

Archaeology has been both the instigator and the victim of this development. It was the intricacies of this interaction, creating cultural realities which could not have been anticipated by the discipline's academic agenda, that intrigued us in preparing this volume, and fuelled the discussion that follows. First, however, we need to explore somewhat further the way archaeology in a young nation-state such as Greece, which was much more than a mere victim of the contradictions inherent in nationalist ideology, becomes the generator of powerful imagery and its supporting narratives.

Greek archaeology and the post-colonial blues

The contemporary world is articulated by national pride. The rediscovery - in effect the invention - of the (national) past was fundamental to the success of the countless nationalist projects in first the West and then the East, as it seemed to guarantee temporal continuity over a spatial unit. Today, following a cascade of border conflicts, humanitarian catastrophes, and waves of ethnic cleansing throughout the globe in the last thirty years or so, nationalism has become a four-letter word. As early as 1973, even before the outbreak of the horrific nationalist wars that were to mar the eighties and nineties, Clifford Geertz was able to state that 'rather like religion, nationalism has a bad name, in the modern world, and, rather like religion, it more or less deserves it' $^{\prime}{ }^{\prime 60}$ and this despite the fact that thinking in a nation-state framework provided the vital ideology that seemed to fulfil, to a great extent, the expectations projected by the Enlightenment - albeit in an exclusively westernized world.

Inspired by the Western European and American mod$\mathrm{el}$, countless ethnic groups and minorities claimed their rights to 'one nation-one state' status in Eastern Europe and the Balkans, Africa, and Asia, creating a commotion that still shows no signs of subsiding. The recent (and ongoing) conflicts between Albanians, Serbs, Bosnians and Croats in the territory formerly occupied by Yugoslavia continue the muddled business of the Balkan Wars of the early twentieth century and the dissolution of the Ottoman Empire in the mid-nineteenth, from which several contemporary states, such as Greece itself, emerged 'liberated'. Viewed as being 'outside modernity', however, non-Occidental nationalisms are perceived as a threat to it or working towards its destabilization. ${ }^{61}$ Whereas the nationalist imagination was once thought of as an admirable - indeed heroic - way of exporting European ideals to the rest of the world, Westerners now feel that this very imagination adulterates its owner's commitment to modernity.

As a discipline devoted to uncovering the past, archaeology is a modern episteme - deeply rooted in a mighty philological tradition (and especially the archaeology of Greece - systematically working within the academic milieu of Classical Studies). Significantly, this tradition was built at a time when the first nation-states were emerging in Europe, and was put to good use as a support mechanism for the nationalist idea itself. Somehow, these once interconnected concepts - nationalist thinking and modern episteme - have now been abruptly divorced from one another, the latter apparently having forgotten where it is coming from, and the former unable to think where it might be going.

If nationalism is widely accepted as a disease, 'especially when it is someone else's', ${ }^{62}$ archaeology is then definitely afflicted by it. Since the mid-nineties archaeologists have been increasingly concerned to rescue their discipline from the pitfalls of nationalist thinking, by means of relocating 'contaminated' discourses and exposing 'invented' traditions. Since the publication of Eric Hobsbawm's crucial essay on 'the invention of [some] tradition[s]' bequeathed to us by our forefathers, ${ }^{63}$ we have learnt to be somewhat suspicious of conventional practices or ethical institutions invested with primordial reverence. Nevertheless one can- 
not help but sense that according to this and many similar theories, some traditions are less 'invented' than others.

When it comes to archaeology, it seems evident that constructions of identity in the nineteenth and early twentieth century have influenced the 'pasts' we are meant to study. Several published volumes of collected essays on various combinations of nationalism, ethnicity, and identity explored this problem. ${ }^{64}$ Whereas these works have invariably been successful in identifying nationalism as the principal force in collective thinking about the past in post-industrial Europe, they seem to me to have failed to see the relevance of archaeology in this discourse. Fair enough, there seems to be little doubt as to the fact that, as Lynn Meskell put it, 'the past has been deployed by Western archaeologists to construct the non-West, to forge ourselves a cultural lineage and to carve out opposing identities' ${ }^{65}$ But what now? Are we to assume that archaeology as a discipline transcends the ideologies, convictions and actions of its practitioners - the 'archaeologists' blamed in the passage quoted above? Can archaeology be extracted from its imperialist, orientalist cocoon and its counter-imperialist, occidentalist manifestations in various parts of the non-Western world? And if it could, would it matter? If we agree to view the past not as an artefact available to our scientific scrutiny, but a field of contention where group feelings, sentiments, and ideas fight against one another, then we will probably sense that archaeology as it stands now might not take us very far; and if we realize that rather than blaming primordial feelings of intimation and kinship manifesting themselves in thoroughly anti-modern ways when it comes to ethnically coloured readings of the past, ${ }^{66}$ we had better gain a clearer understanding of the relationship between history, culture, and sentiment (public or private), then we might come up with an archaeology worthy of the money and energy invested in it. Needless to say, this would require a thorough rethinking - a de-constitution - of the founding concepts of archaeology, as a 'first step outside of it', in the way Derrida once urged philosophers to do with philosophy - not as a strictly philological or historical exercise, but as a purely philosophical one. ${ }^{67}$

Stepping outside of the paradigm is indeed a very demanding task that not everyone is willing to undertake. In 1994 Ian Morris published a thorough and critical survey of the archaeological debate in and about Greece. ${ }^{68}$ As in the series of collective publications mentioned above, this too tries to rescue archaeology from its lethal entanglement with nationalism and other such horrors of the past (or rather the past abroad). As most of these publications' titles suggest (Archaeology and Nationalism; Histories and Archaeologies, etc), archaeology is not seen as an actual part of the nationalist discourse, but as an independent agent, seriously and grievously affected by it. Morris is very accurate in his description of the fierce conflict between Western European readings of Classical Greece and its nationalist uses by modern Greeks themselves - 'a complex matter', indeed. Intentionally confusing Droysen with Foucault, he talks of 'Hellenism', the drive on Europeanness behind what Foucault has described in his Les mots et les choses as the shift from the classical to the modern episteme. ${ }^{69}$ By concocting 'Hellenism' as an addition to Trigger's three types of archaeologies in modernity (nationalist, colonialist, imperialist),${ }^{70}$ Morris seems to me somewhat to obscure (classical) archaeology's debt to one of modernity's main - albeit often underestimated - components, namely Romanticism, to which nationalism, empiricism, and individualism, can all be shown to be related. And as we shall see in the papers that follow, all these components have shaped Greek archaeology as we know it: a discipline inspired (as archaeology by definition is) by the conviction that rigorous methodology and positivist discourse is bound to lead to valid, objective results; and that comprehensive analysis of the material remains reveals the national character of the people that produced them.

The German Altertumswissenschaft movement, and the wider tradition of nationalist Romanticism it expressed, can be detected as the primary source of inspiration behind these notions. ${ }^{71}$ The fact that certain of its spin-offs have been taken up by projects such as Greek nationalism and positivist archaeology, which claim to be irreconcilable with one another, is to be attributed to the particular aims of these projects rather than the essential qualities of Romantic ideas in themselves. Greek archaeology in the twentieth century shared the fortunes, blessings, and tribulations of modernity itself; and the rift created between the 'metaphysical' and the 'positivist' archaeological discourses, is yet another battle in the post-colonial wars.

Admittedly, Greek art has become a modern commodity, to be enjoyed as image and spectacle, as the charming representation of an imaginary ancestry; this has been the universal fate of art works in late modernity. ${ }^{72}$ In Greece, it was conscripted into the efforts to forge the nation's primeval ties with its psyche, lost in the depths of Aegean 
prehistory, a quite spectacular notion, as the Olympic ceremony demonstrated. Greek nationalism sought its cultural expression in classical and pre-classical antiquity, and Greek archaeologists in the nineteenth and twentieth centuries managed to promote the modernity of Greece based on the antiquity of Hellas - both cultural topoi, of course, and quite imagined ones at that. As a 'political community' imagined by its members, ${ }^{73}$ Greece - represented by its intellectuals - strove to embrace modernity through an idiosyncratic connection with the past, expressed by means of the ideological scheme of Hellenicity; thus, Greece's glorious past was seen as the guarantor of its splendid future.

Hellenicity, and its subsidiary notions of national continuity, singularity, superiority, are anguished expressions of a deeply rooted Occidentalism, an instinctive - albeit strategically planned and consistent - reaction to the gaze of the West, often disapproving or even scornful. This is a Lacanian gaze, pretty much imagined by the subject in the field of the Other. ${ }^{74}$ National identity had to be formed and propagated against a backdrop of (occidental) modernity and the crucial dilemma between modernization (which everybody craved, if surreptitiously) and westernization (feared to be the kiss of death to any non-Western society).

The generation of the thirties balanced the blessings and the horrors of both predicaments, hence the long afterlife enjoyed by their ideas. Similar developments have been observed elsewhere, such as in the early twentieth-century Bengal school of art, whose efforts to define an aesthetic form, at the same time modern and national, for the art of India would appeal to any Greek intellectual from the thirties up to the present day. ${ }^{75} \mathrm{It}$ is this continuous oscillation between desire for and resistance to the West ${ }^{76}$ that shapes Greek sensibilities towards antiquity and its artefacts, be they Early Cycladic figurines or the Elgin Marbles. Greeks invite the gaze of the West, seeking its approval and challenging its scorn. The discourse of Hellenicity provides a flexible apparatus, through which to bypass modern failings, since antiquity affords ample credentials. The Olympic ceremony described in the beginning of this paper exemplifies this strategy - Greece seeks the approval of the West, which it deserves ... simply for being Greece.

Hellenicity and its instrumental sentiment of archaeolatry - shared by intellectuals and laymen alike, conservative, liberal, even communist - find expression in massive,
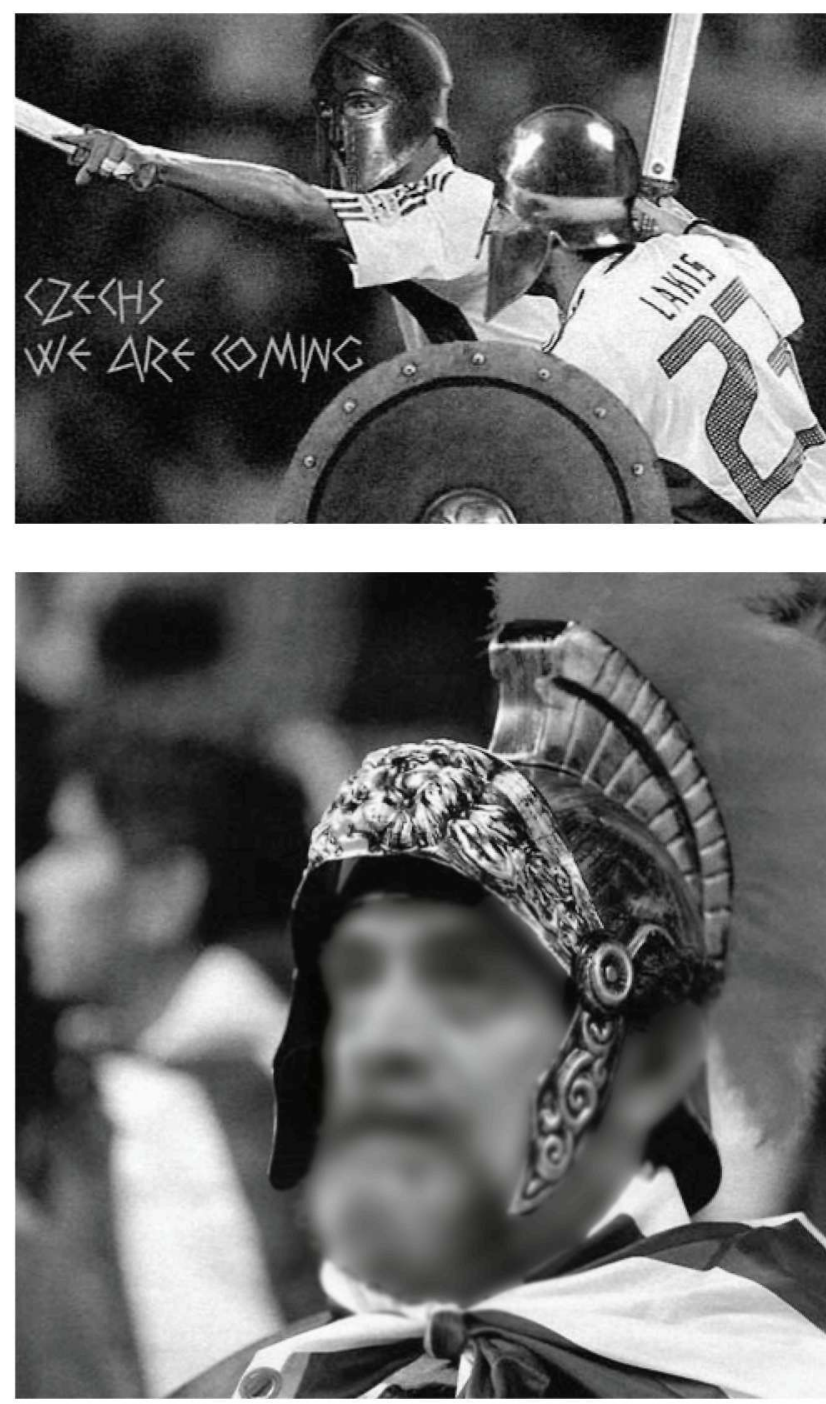

Fig. 5. 'Czechs, we are coming!': a digitally manipulated image of two Greek football players circulated on the Internet during the 2004 European Football Championship.

Fig. 6. A frustrated Greek football fan in ancient headgear during the 2004 European Football Championship (@Action Images).

exhilarating displays of patriotism, at once reassuring and therapeutic, Greece's own experience of an 'erotics of nationhood'. ${ }^{77}$ Big sports events are nowadays commonly associated with such displays where Greek nationality - portrayed through the imagery of the nation's singular antiquity - is evoked to boost team spirit (fig. 5), or as a consolation against the adversities of fate (fig. 6). Though generally performed in a climate of innocent fun, these 


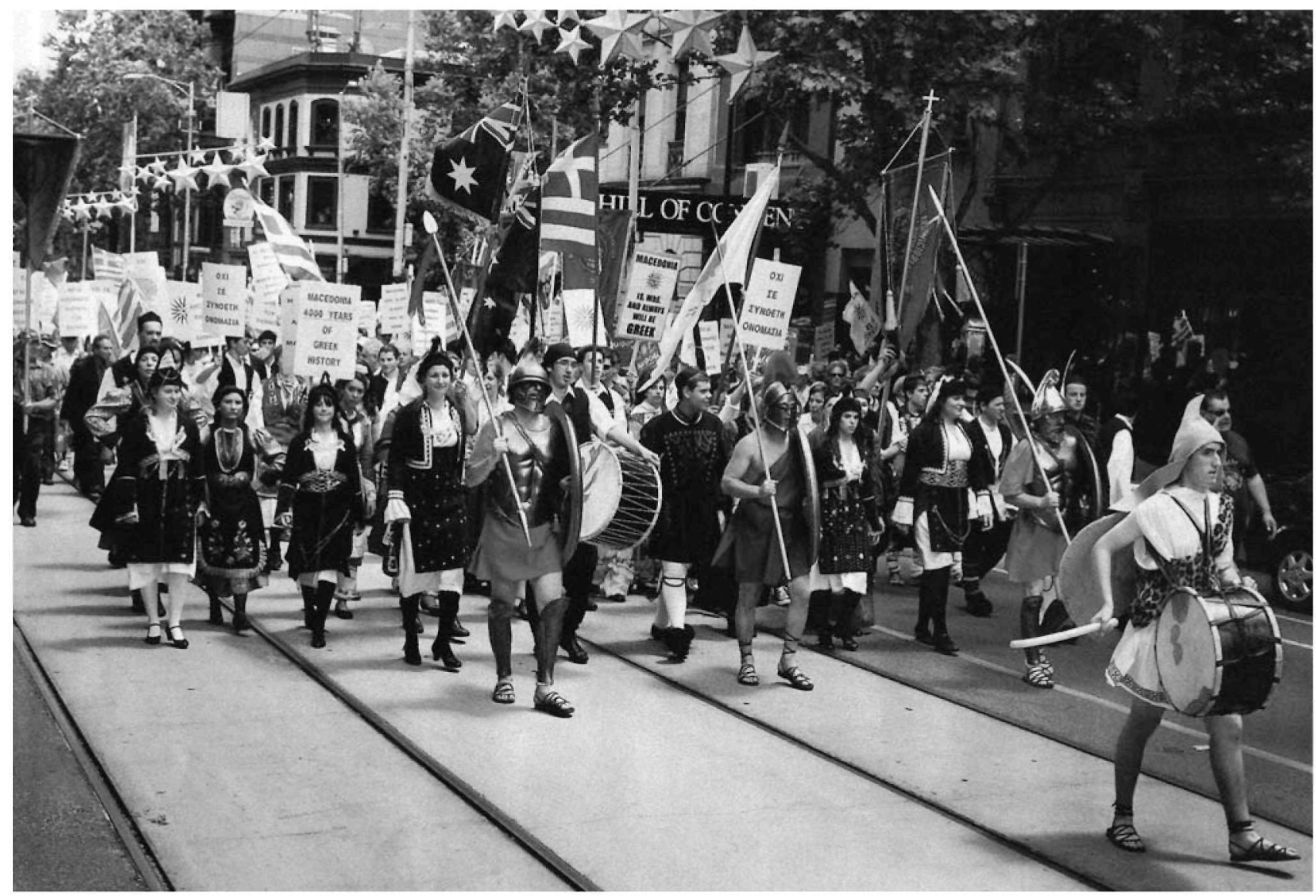

Fig. 7. Australian Greeks demonstrating in Melbourne dressed as 'ancient Macedonians' (source: Bimagazino, 25 November 2007, 18).

mass rituals can sometimes show a truly menacing face: the Greek football team's triumph in the 2004 European Cup in Lisbon (a national triumph indeed) was celebrated in the streets of Athens with many chants, all suitably sexist or racist, including one along the lines of 'Hey, Albanian! a Greek you'll never be!', followed by violent attacks against Albanian immigrant bystanders, even though their country was not taking part in the tournament in the first place. ${ }^{78}$ Cultural distinction has become the primary function of Hellenicity in national discourse, especially when it comes to 'national issues' such as Greece's disputes with its neighbours. Ancient imagery is time and again employed to suggest ownership of the past and cultural superiority, as in the case of public protests (many of which took place abroad, in countries with a sizeable community of Greek immigrants) regarding the so-called 'Macedonian issue' (fig. 7). ${ }^{79}$

Studying antiquity, therefore, entails the study of con- temporary culture, through which antiquity is imagined before it even begins to be studied. In effect the 'antiquity' we end up studying has become, now more than ever, one of the culture industry's favourite fields of action. Despising the culture industry as an agent attempting the purposeful integration of its consumers 'from above', as Adorno has described it, ${ }^{80}$ and rejecting its products as fraudulent ideologies, overlooks the fact that this same industry can spawn 'moments of conflict, rebellion, opposition and the drive for emancipation and utopia, ${ }^{81}$ perhaps accidentally, innocently or even inadvertently, though genuinely nonetheless. The Greek example alone would suffice to uphold this statement: as imagined by intellectuals (including archaeologists) from as early as the late nineteenth century, the Greek heritage functioned as the mystic's crucible where the nation's 'antiquity' met its primeval, therefore remarkable, 'modernity'. Archaeolo- 
gists in particular sought to exemplify the nation's structured past, based on the twin, metaphysical notions of 'nation-time' and 'nation-space'. ${ }^{82}$ This produces the kind of frustrated, emancipator archaeology still in evidence in Greece, and other 'young' nation-states.

As an imagined community, Greece - contrary to the popular orientalist stereotype which wants to view nonoccidental societies as monolithic, singular units reeking of nationalist spite and anti-modern resilience - is split by unfathomable rifts between exponents of traditionalism and progress, invariably expressed through the discourse of Hellenicity within or beyond the West. Most, if not all, national projects in the field of archaeological research or cultural management subscribe to this goal, often including in their official rhetoric statements to that effect.

We have by now learnt to accept that the archaeologies we produce are generated in the mill of controversy, rebellion, and shared fantasy $y^{83}$ and that, far from dealing with 'reality', they are meant to help their audience deal with their own experiences of culture, time, and mortality. However irrational or regressive, such projects are meant to articulate the logos of the nation and at the same time chart its topography. ${ }^{84}$ They can also be used to turn cultural stereotypes on their heads: Greece, perpetually seen as 'Orient' by its friends and foes alike, behaves as part of the Occident (as one of the West's founding ... mothers, so to speak) both to its western and eastern neighbours. Greek nationalists, as early as the late nineteenth century, produced rhetoric of remarkably orientalist overtones, urging the nation to assume its task of 'civilizing the Orient'. ${ }^{85}$

Whereas the Greeks themselves believe their state to be the direct outcome of their nation's glorious revolt against its bloodthirsty oppressor, an external view of these events would suggest that modern Greece is a product of the West, sprouting from a happy coincidence of political interests and intellectual preferences. Romantic Philhellenism enabled captive Greeks to make their case appealing to European ears. However, once the great cause was achieved, it became apparent that Greece and its protectors had been working towards different ends. What for Greek intellectuals and their ever growing audience (at home rather than abroad) was the cradle of European civilization, was for their Western patrons the incarnation of a long-lost fantasy, hotly pursued, though orientalist nonetheless. ${ }^{86}$ Following the dissolution of the Ottoman Empire, Greece emerged as an Orientalist's Neverland, where truth was 'stranger than fiction', ${ }^{87}$ and where boys never grew old and poets gained immortality, especially if they met an early death in the marshlands of Missolonghi. (As a matter of fact, had Byron survived his sad predicament, the history of Philhellenism might have taken a quite different turn.) Once the Greek state came to life, it was found to embody all the failings customarily (and 'naturally') associated with the Orient: ${ }^{88}$ it was disorganized, inefficient, and irrational. Today, describing the Greek War of Independence (to stick to standard terminology) as 'that curious combination of civil war, amateur freedom-fighting and professional atrocity ${ }^{89}$ seems enough to silence the natives - Greek or other - once more,$^{90}$ reserving for the critics the right to represent the Other at will.

Archaeology finds itself unwittingly entangled in this mesh of contradictory agendas, where what is at stake may be the very way we view the world and our role in it. Detached and objective, archaeology is time and again called in to perform the crucial role of producing the 'facts' we need in order to represent the past as an artefact available to our scrutiny.

From where we stand...

Although this is not a book about nationalism, orientalism, colonialism or globalization, these issues will emerge in many of its papers. Archaeology in early twenty-firstcentury Greece carries the burden of its twentieth-century predicament. I chose to describe the Olympic ceremony at the beginning of my introduction as a ritual that, to my mind, attempted to close a traumatic, and short, Greek twentieth century with a flare of introspective resilience. I believe that the ceremony serves as a poignant reminder that collective Greek imaginings remain faithful admirers and enthusiastic consumers of both the metaphysical veneration of the Greek landscape which dates back to the very beginning of the twentieth century, and the even earlier systematization of Greek history as a single, continuous and unmediated phenomenon. Both concepts were fertilized, of course, by the vision and the fervour of the intellectuals who made up the generation of the thirties, though inevitably influenced by the violent political and ideological clashes of the inter-war years.

The Hellenicity discourse as a national project relies on archaeology as purveyor of the necessary imagery and 


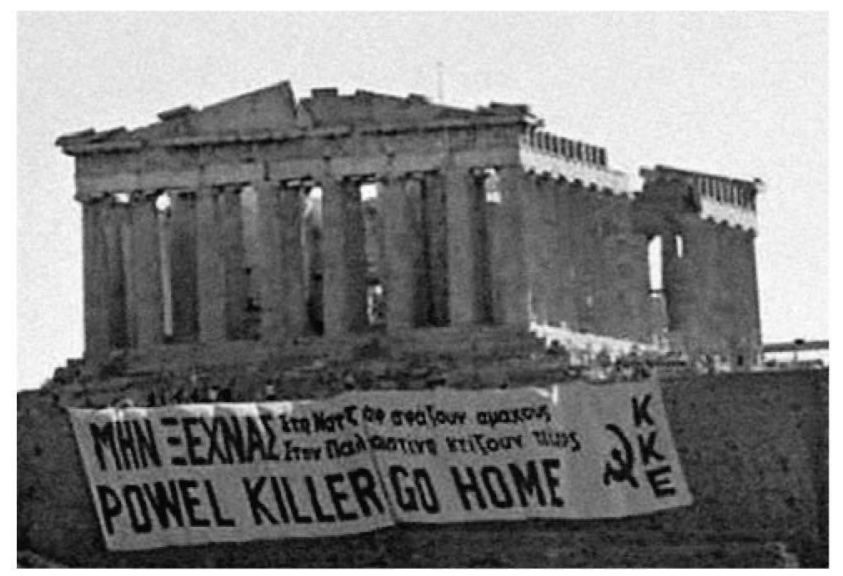

Fig. 8. 'Powel (sic) Killer Go Home!': The Greek Communist Party chooses the Parthenon as the backdrop for its demonstration against the US Secretary of State, 28 August 2004.

the supporting scientific documentation. Its poignantly aestheticized rhetoric equates Greek culture with its aesthetics, activated in two separate fields: Greek art (Prehistoric, Classical, Byzantine, post-Byzantine) and the Greek landscape (natural or man-made). Archaeology is in charge of the production of both as cultural topoi, sites of national convergence and (more often than not) conflict. To achieve this, it has had on the one hand to adopt an essentialist view of 'Hellenic' art in its various embodiments and on the other to promote a hellenocentric approach to other historical and art historical phenomena. As Greek archaeologists - from their respective standpoints as university teachers or government officials - were claiming an ever increasingly central role in the ideological and actual management of Greece's cultural capital, research ethics and practices in Greek archaeology were progressively (and unavoidably?) aligned with a markedly antiquarian approach to the past, ignoring newer developments in archaeological science and related disciplines. Thus archaeology in Greece - Prehistoric, Classical, and Byzantine - became predominantly Greek (or Helladic, to be exact). Choosing to steer an introvert, and decidedly conservative course, Greek archaeology would seem in the post-war years to have confined itself to the role of keeper of national ideologies, as they were devised on its behalf by the Greek state and communicated, promoted and propagated through a deeply conservative educational system.
Both the 'Great Idea' and the discourse on Hellenicity as moves for national self-determination affected the ideology and the praxis of Greek archaeology. Instigated by intellectuals, though supported, recycled and eventually redefined by the public at large, these moves express the need to articulate the image of the land and its people with respect to Western and global culture, as a way of claiming patrimonial intellectual and political rights.

Since the mid-twentieth century Greeks seem to have defined their relationship with their past somewhere between two opposing extremes: a liberal re-evaluation of heritage on the one hand, drawing its genealogy from Romanticism and its metaphysical aspects, and narrowminded archaeolatry on the other, introvert and sterile, and something to fall back on every time the nation is in trouble - whether real or imaginary. Antiquity is invariably used as the scenery of Greece's present achievements, as well as its frustrations (fig. 8). Politically, archaeology is deployed as an explicit legitimizing force or even a disciplinary measure. In the early nineties, reacting to Greece's insistence that its hereditary rights be the sole basis for resolving the 'Macedonian issue' (and at a time when the state was threatening with prison sentences all Greeks voicing opinions contrary to the official national line, and invoking school history books and the finds from Vergina against the country's northern neighbours), The Spectator published a drawing of the Parthenon turned into a concentration camp. ${ }^{91}$ As if to confirm the disciplinary powers of archaeology - let us not forget that Foucault's heterotopias of deviation include 'rest homes and psychiatric hospitals, and of course prisons ${ }^{\prime 22}$ - the Greek state has decided to illustrate the passports of its citizens with images of the Parthenon, the ossuary from Vergina, Mistra and Mt. Athos, presumably as a means to propagate an identity to the exclusion of all others. Interestingly, the recipients of this message are none other than the Greeks themselves, since passports, with the exception of a fleeting surrender at border crossings, remain in the keeping of their owners. Like any tradition, invented or otherwise, such visual reminders of cultural and political belonging 'attempt to establish continuity with a suitable historic past'. ${ }^{93}$

The papers that follow endeavour to illustrate developments in Greek archaeology during the twentieth century: formation of ideas and epistemological programme, interaction with other disciplines and projects, involvement with the country's intellectual and political life, respond- 
ing to the public's desires and dispositions. The two Greek Olympics of 1896 and 2004, as two important landmarks for which Greek heritage was summoned to fashion the appropriate ideological backdrop, will act as symbolic termini for our investigation. The first part of the volume, Antiquity and the Greek Antiquities, explores the ways in which Greece dealt with its historical past and the material remains it inherited as a modern state. The second part, Greek Archaeology: Paradigms and Ideologies explores the epistemic strategies and idiosyncratic tendencies through

\section{NOTES}

1. On the Olympic procession, see also Simandiraki 2005; Hamilakis 2007, 1-9.

2. Baudrillard 1994, 1-42.

3. Cf. Renfrew 1991, 81 fig. 54. Another replica of the Goulandris statuette, of the kind marketed by the Museum of Cycladic Art Shop, is featured in the opening and closing scenes of Alexander Payne's 2004 film Sideways, presumably as a tongue-in-cheek reminder of the Greek-American director's own 'Hellenic' roots.

4. Cf. Gellner 1983, 56.

5. Admittedly, Papaioannou 'redeemed' himself with his closing ceremony for the 2004 Olympics, where he presented a show based on post-classical Greek history and present-day experience - from folk dances to plastic chairs at the beach and from gypsy water-melon vendors to bouzouki night-clubs. In contrast with the opening ceremony, here there was only a passing, sarcastic reference to classical antiquity, alluding to its touristic exploitation by modern Greeks. Needless to say, the closing ceremony received a more lukewarm welcome, from the nationalists and the 'purists'.

6. See Lowenthal 1988; Hamilakis \& Yalouri 1996; Mouliou 1996; Kotsakis 1998; Hamilakis 2007, 57-123.

7. Potts 1994, 37.

8. Anderson 1991, 163-85.

9. Said 1993, 16.

10. Delivorrias 2000, 27.

11. As advertised by the Museum's web site: http: //www.benaki.gr/collections/greece/en/, last accessed 1 May 2008. The blurb goes on to specify the time span covered: 'from antiquity and the age of Roman domination to the medieval Byzantine period, from the fall of Constantinople (1453) and the centuries of Frankish and Ottoman occupation to the out- which Greek archaeology emerged as an independent discipline in the twentieth century. Finally, a third part, The Imagined Realities of Greekness, charts the interaction between the discourse on Hellenicity and Greek perceptions of its classical heritage, which led to the creation of an immensely popular and culturally dominant strain of public archaeology in twentieth-century Greece.

Dimitris Plantzos

dkplantzos@yahoo.gr break of the struggle for independence in 1821, and from the formation of the modern state of Greece (1830) down to 1922, the year in which the Asia Minor disaster took place'. It is clear from this text that, throughout Greek history, only the contributions of the Hellenes to Greek culture and art are legitimate; all others (representing sad breaks in the 'natural' flow of things) are conquerors waiting to be charmed by the Greek spirit rather than likely to advance it. More to the point, whereas the Frankish and Ottoman periods are usually dubbed 'occupations', the Byzantine period (when Greece proper was a more or less insignificant part of the East Roman Empire) is universally accepted as a trully 'Hellenic' age.

12. The recently refurbished permanent exhibition at the Benaki Museum spans several millennia from Cycladic art to the two Nobel and the one Lenin prize won by Greeks in the 20th c., all for poetry. It ends with a Karaghiozis screen and figures looming in the background, a spectre, as its Cycladic counterpart, of (an)Other culture which the Greeks made their own through tradition, translation, and inertia. A short tribute to Karaghiozis was, naturally, included in the 2004 Olympic procession.

13. See Plantzos 2007; Labrusse 2006.

14. Petrakos 1987, 17.

15. Foucault 1986.

16. Foucault 1986, 24.

17. Leontis 1995, 40-66.

18. Leontis 1995, 44.

19. Gourgouris 1996, 46.

20. Hamilakis 2007, 17.

21. Valavanis 2007, 13.

22. Mallouchou-Tufano 2007, 48-51.

23. Mallouchou-Tufano 2007, 50. 
24. Quoted in Mallouchou-Tufano 1998, 240.

25. Mallouchou-Tufano 1998, 241.

26. Papageorgiou-Venetas 1994, 238-42.

27. Cf. Hamilakis 2007, 35-56.

28. This practice reported favourably on this Greek site: http://www.athensinfoguide.com/gr/wtsmuseums/acropolismuseum.htm, and with some bemusement on these two travelogues by foreign visitors to Greece (among many others): http// www.cherba.com/i2p/i2p-greece_body.htm; http//www.greeklandscapes.com/travel/photographing_in_greece.html, all last accessed 8 May 2008.

29. Cf. the blog http://areopagitou17.blogspot.com, last accessed 21 April 2008, voicing protests against the Ministry's decision.

30. See the discussion in Lekakis 2007.

31. Cf. Y. Kizis in Kathimerini, 21 July 2007; Mitzalis 2007.

32. See Fabian 1983, 106-9.

33. Text by Nikos Dimou in the lifestyle magazine Lifo, 29 November 2007.

34. Though never explicitly stated in official documentation, this is generally understood both in Greece and abroad as the central issue of the debate (cf. The Observer, 29 July 2007); cf. the heated discussion at a web-based chat group of Greek photographers: http://flickr.com/groups/greeks_on_contemporary_greek_life/discuss/72157600869826566/?search $=17$, last accessed 28 April 2008, where the majority of participating 'Neo-Hellenes' claim that the two condemned buildings are not 'ancient enough' or even 'artistic', 'beautiful' or 'suitably Hellenic' to stand in the way of the Parthenon, thus subconsciously (though quite explicitly) pushing for a 'cleansed', historically sterilized and all-Greek Athenian landscape.

35. Veltsos 1983, 227.

36. Skopetea 1988, 171-89; Kyrtatas 2002, 91-131; Clogg 1992, 1-6.

37. Herzfeld 1986, 13-18; 24-52; Dimaras 2002, 283-99; Dimaras 2004, 428-41.

38. See Skopetea 1988, 105-6; 179-80; Dimaras 2004, 325404.

39. Liakos 1994; Skopetea 1988, 179-89; Dimaras 2002, 391-410; Voutsaki 2003, 232-37.

40. Tziovas 1989, 146-47; Herzfeld 1986, 97-122.

41. Peckham 2001, 76-88; Vitti 1984, 195-224; Tziovas 1989, 73-93; 113-52.

42. Voutsaki 2002, 120-21.

43. Clogg 1992, 46-97; Veremis 1983; Skopetea 1988, $249-$ 360; Herzfeld 1986, 123-39; Dimaras 2004, 359-63; 404-18. In 1844 , the same year when he publicly spoke about the 'Great
Idea of the nation', Ioannis Kolettis (Prime Minister of Greece at the time, as well as President of the Board of the Archaeological Society at Athens) stressed the need for a national archaeology acceptable to scholars abroad, notably 'muse-breeding' Germany (Skopetea 1988, 202 n. 35; cf. Kalpaxis 1996).

44. Clogg 1992, 98-106.

45. Vitti 1984; Tziovas 1989.

46. A reappraisal of national qualities had been the main theme in fascist rhetoric in nearby Italy, where the effort to identify and study italianità may have encouraged at least some of the promoters of Hellenicity in Greece; at the same time Spain was strengthening its own sense of hispanidad, encouraged by General Franco's regime; cf. Vitti 1984, 200.

47. Tziovas 1989, 73. Tributes to Giannopoulos have now become commonplace among Greek nationalists, mostly internet-based anthologies of patriotic rhetoric such as: http:// ethnikistes.blogspot.com/2008/04/1869-1910.html, last accessed 8 May 2008 (a page devoted to Giannopoulos as a 'worshipper of Hellas' uploaded as recently as 22 April 2008). Verging on the ridiculous, a Greek hip-hop band bombasting ultra-rightwing rhetoric in their 'patriotic' lyrics, feature a homage to Giannopoulos in a recent hit (published nonetheless by the mainstream Greek record company 'Heaven Music'), campaigning for a 'renaissance of fundamentalist Greek spirit' through the adoption of new 'true' role models, such as the long-dead exponent of uninhibited Greek Romanticism (http://www.youtube.com/ watch?v=y9erDVrpWJU, last accessed 8 May 2008).

48. Vitti 1984, 212-15; Tziovas 1989, 78-82.

49. Cf. Lambropoulos 1984.

50. Vitti 1984, 195-224; Tziovas 1989, 139-52; Hamilakis 2007, 169-204.

51. Tziovas 1989, 153-63.

52. Hadjinikolaou 1982.

53. Cf. Hadjinikolaou 1982, 64 (referring to the work of Nikos Hadjikyriakos-Ghika).

54. Cf. Leontis 1995, 89-99.

55. Vitti 1984, 202-5.

56. As reported by Marios Ploritis in the daily newspaper Eleftheria, 1 September 1959.

57. Clogg 1992, 149.

58. 'Worthy is thy prize', a clear reference to Elytis' magnum opus To Axion Esti, was the title of a laudatory review of the Olympic opening ceremony in the daily newspaper $T a N e a$, written by the paper's resident theatre critic Kostas Georgousopoulos: Ta Nea, 14 August 2004. Cf.: '[Papaioannou] grasped the complete consciousness of Greek diachronicity, honouring the profound construction of Greek thought'.

59. Dimaras 1983, 238.

60. Geertz 1973, 253. 
61. Chatterjee 1993, 3-13; Appadurai 1996, 139-57.

62. Appadurai 1996, 19.

63. Hobsbawm 1983.

64. Cf. Diaz-Andreu \& Champion 1996; Atkinson et al. 1996; See also Meskell 1998.

65. Meskell 1998, 3.

66. Cf. Appadurai 1996, 139-57.

67. Derrida 1978, 278-93.

68. Morris 1994; cf. Shanks 1996, 53-91.

69. Foucault 1970, esp. 46-77.

70. Trigger 1984; Trigger 1989, 110-47.

71. Morris 1994, 23-6; Voutsaki 2002, 107-13.

72. Huyssen 1986, 21-25.

73. Cf. Anderson 1991, 1-7.

74. Lacan 1998, 79-90.

75. Chatterjee 1993, 8. Nationalist rhetoric in India of the thirties was constructed along lines that are strikingly familiar to any modern Greek. Raja Rao's Kanthapura, his great novel about Indian nationalism, written in English and published in 1938 , provides the essence of Indianness against a culturally inferior West: 'We cannot write like the English. We should not. [...] We, in India, think quickly, we talk quickly, and when we move we move quickly. There must be something in the sun of India that makes us rush and tumble and run on. And our paths are paths interminable. [...] - we tell one interminable tale' (Rao 1963, vii-viii); see Buell 1994, 74-86.

76. Cf. Liakos 2005, 106.

\section{REFERENCES}

Adorno T. 1991: The Culture Industry: Selected Essays on Mass Culture (ed. by J.M. Bernstein; London and New York).

Anderson B. 1991: Imagined Communities: Reflections on the Origin and Spread of Nationalism (2nd revised edition; London and New York).

Appadurai A. 1996: Modernity at Large: Cultural Dimensions of Globalization (Minneapolis and London).

Atkinson J.A. et al. (eds) 1996: Nationalism and Archae$\operatorname{ology}$ (Glasgow).

Baudrillard J. 1994: Simulacra and Simulation (transl. by S.F. Glaser; Ann Arbor).
77. Appadurai 1996, 110-13.

78. Onoufriou 2005; cf. Giannakopoulos 2005.

79. Cf. Kotsakis 1998.

80. Cf. Adorno 1991, 98-106.

81. Bernstein 1991, 21.

82. Bhabha 1994, 199-244.

83. Cf. Schnapp 2004; Hamilakis 2004.

84. Cf. Appadurai 1996, 178-99.

85. Dimaras 2004, 238; Skopetea 1988, 175-89.

86. Skopetea 1988, 218-30.

87. Byron, Don Juan, Canto XIV, 101. Cf. Skopetea 1992, 46.

88. Said 1994, 31-49.

89. Beard 2003,68 , pointing out - quite rightly - that 'less attention has been devoted to the monuments of Turkish Greece than to any other period of the country's archaeology'. But to what extent can this be used to counter Greek claims (however well founded themselves) regarding the ownership of the Elgin marbles?

90. Cf. Petsalis-Diomidis 2003, 192-94.

91. To Vima, 30 August 1992; cf. Philippides 1994, 303 fig. 41. On the Vergina excavation with regard to the 'Macedonian issue', see Kotsakis 1998; Hamilakis 2007, 125-67.

92. Foucault 1986.

93. Hobsbawm 1983, 1.

Beard M. 2002: The Parthenon (London).

Bernstein J.M. 1991: Introduction, in: Adorno T., The Culture Industry: Selected Essays on Mass Culture (ed. by J.M. Bernstein; London and New York) 1-28.

Bhabha H.K. 1994: The Location of Culture (London and New York).

Buell F. 1994: National Culture and the New Global System (Baltimore and London).

Clogg R. 1992: A Concise History of Greece (2nd edition; Cambridge).

Chatterjee P. 1993: The Nation and its Fragments: Colonial and Postcolonial Histories (Princeton). 
Delivorrias A. 2000: A Guide to the Benaki Museum (Athens).

Derrida J. 1978: Writing and Difference (transl. by Alan Bass; Chicago).

Diaz-Andreu M. \& Champion T. (eds) 1996: Nationalism and Archaeology in Europe (London).

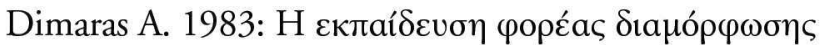

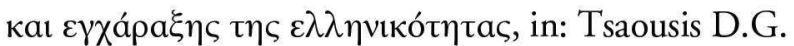

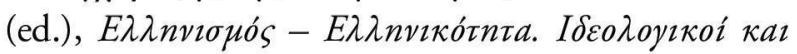

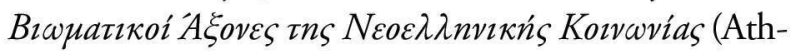
ens) 235-41.

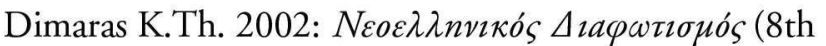
edition; Athens).

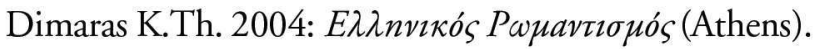

Fabian J. 1983: Time and the Other: How Anthropology makes its Object (New York).

Foucault M. 1970: The Order of Things: an Archaeology of the Human Sciences (New York).

Foucault M. 1986: Of other spaces, Diacritics 16(1), 2227.

Geertz C. 1973: The Interpretation of Cultures (New York).

Gellner E. 1983: Nations and Nationalism (Ithaca).

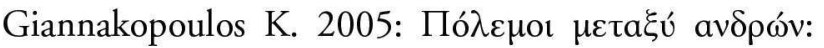

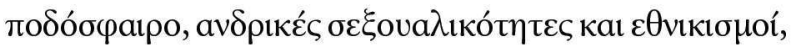

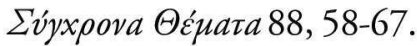

Gourgouris S. 1996: Dream Nation: Enlightenment, Colonization and the Institution of Modern Greece (Stanford).

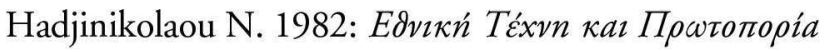
(Athens).

Hamilakis Y. 2004: The fragments of modernity and the archaeologies of the future, Modernism/Modernity 11(1) 55-59.

Hamilakis Y. 2007: The Nation and its Ruins: Antiquity, Archaeology, and National Imagination in Greece (Oxford).

Hamilakis Y. \& Yalouri E. 1996: Antiquities as symbolic capital in modern Greek society, Antiquity 70, 117-29.

Herzfeld M. 1986: Ours Once More: Folklore, Ideology, and the Making of Modern Greece (New York).

Hobsbawm E. 1983: Introduction: Inventing Traditions, in: Hobsbawm E. \& Ranger T. (eds), The Invention of Tradition (Cambridge).

Huyssen A. 1986: After the Great Divide: Modernism, Mass Culture and Postmodernism (London).

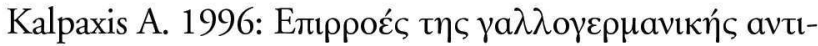

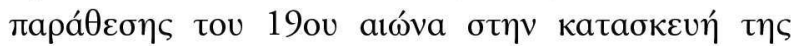

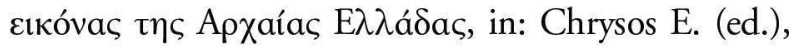

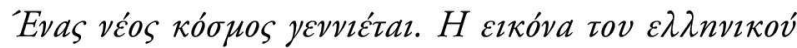

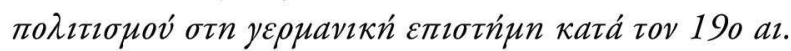
(Athens) 41-58.

Kotsakis K. 1998: The Past is Ours: images of Greek Macedonia, in: Meskell L. (ed.), Archaeology under Fire: Nationalism, Politics and Heritage in the Eastern Mediterranean and Middle East (London and New York) 44-67.

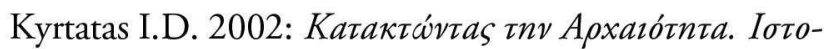

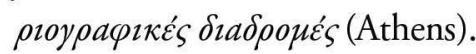

Lacan J. 1998: The Four Fundamental Concepts of Psychoanalysis. The Seminar of Jacques Lacan, Book XI (ed. by J.-A. Miller and transl. by A. Sheridan; 2nd edition; New York and London).

Labrusse R. 2006: Dieux cachés, mirages des origines, in: Derouet C. (ed.), Cahiers d'art. Musée Zervos à Vézelay (Paris) 39-59.

Lambropoulos V. 1984: The aesthetic ideology of the Greek quest for identity, Journal of Modern Hellenism 4, 19-24.

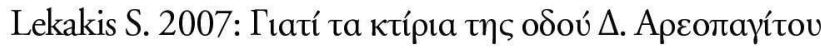

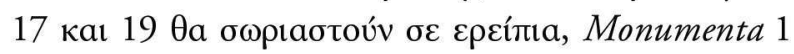
(http://www.monumenta.org/article.php?perm=1\&Is sueID $=2 \&$ lang $=$ gr $\&$ CategoryID $=19 \&$ ArticleID $=107$, last accessed 23 April 2008).

Leontis A. 1995: Topographies of Hellenism: Mapping the Homeland (Ithaca and London).

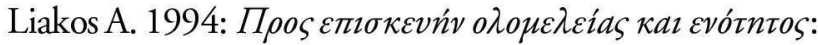

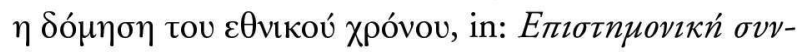

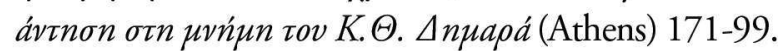

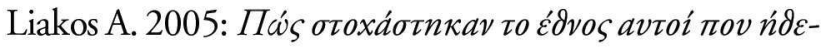

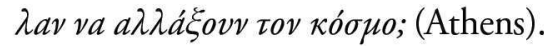

Lowenthal D. 1988: Classical antiquities as national and global heritage, Antiquity 62, 726-35.

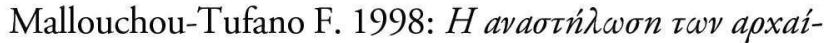

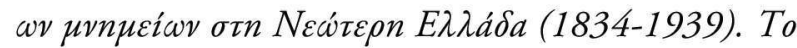

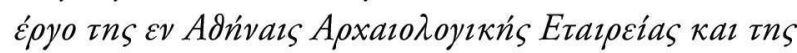

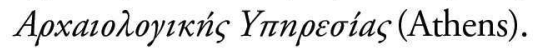

Mallouchou-Tufano F. 2007: The vicissitudes of the Athenian Acropolis in the 19th century: from castle to monument, in: Valavanis P. (ed.), Great Moments in Greek Archaeology (Athens) 36-57.

Meskell L. 1998: Archaeology matters, in: Meskell L. 
(ed.), Archaeology Under Fire: Nationalism, Politics, and Heritage in the Eastern Mediterranean and Middle East (London and New York) 1-12.

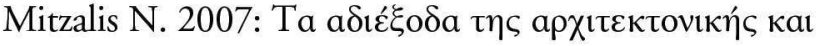

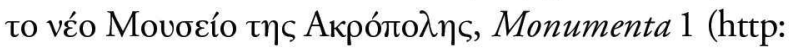
//www.monumenta.org/article.php?perm=1\&IssueID $=2 \&$ lang=gr $\&$ CategoryID $=19 \&$ ArticleID $=104$, last accessed 23 April 2008).

Morris I. 1994: Archaeologies of Greece, in: Morris I. (ed.), Classical Greece: Ancient Histories and Modern Archaeologies (Cambridge) 8-47.

Mouliou M. 1996: Ancient Greece, its classical heritage and the modern Greeks: aspects of nationalism in museum exhibitions, in: Atkinson J.A. et al. (eds), Nationalism and Archaeology (Glasgow) 174-99.

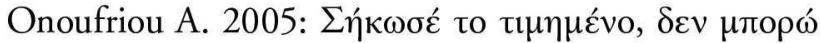

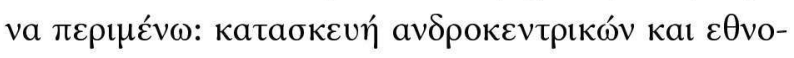

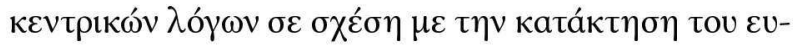

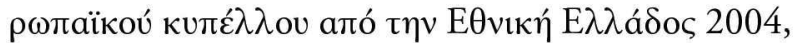

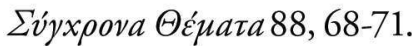

Papageorgiou-Venetas A. 1994: Athens: the Ancient Heritage and the Historic Cityscape in a Modern Metropolis (Athens).

Peckham R.S. 2001: National Histories, Natural States: Nationalism and the Politics of Place in Greece (London and New York).

Petrakos V. 1987: H Ev Adńvaıs A

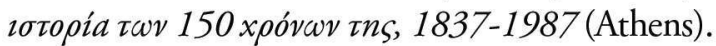

Petsalis-Diomidis A. 2003: Twenty-first century perspectives on the Parthenon, The Journal of Hellenic Studies 123, 191-96.

Philippides D. 1994: The Parthenon as appreciated by Greek Society, in: Tournikiotis P. (ed.), The Parthenon and its Impact in Modern Times (Athens) 278-309.

Plantzos D. 2006: 'Grèce mensongère': Christian Zervos and the rehabilitation of Cycladic Art in: Stampolidis

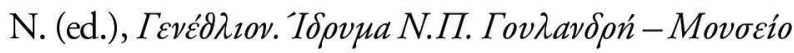

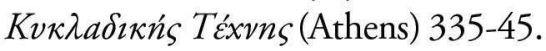

Potts A. 1994: Flesh and the Ideal: Winckelmann and the Origins of Art History (New Haven and London).

Rao R. 1963: Kanthapura (New York).

Renfrew C. 1991: The Cycladic Spirit: Masterpieces from the Nicholas P. Goulandris Collection (New York).
Said E.W. 1993: Culture and Imperialism (New York). Said E.W. 1994: Orientalism (2nd revised edition; New York).

Simandiraki A. 2005: Minoan Archaeology in the Athens 2004 Olympic Games, European Journal of Archaeology 8, 157-181.

Shanks M. 1996: Classical Archaeology of Greece: Experiences of the Discipline (London and New York).

Schnapp J.T. 2004: Excavating the Corporativist City, Modernism/Modernity 11(1) 89-104.

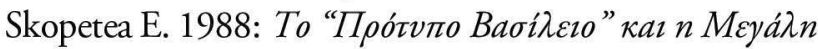

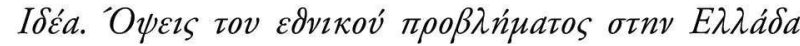
(1830-1880) (Athens).

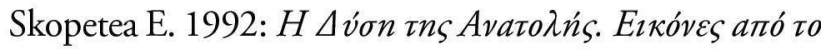

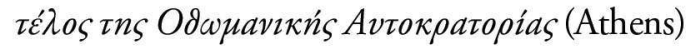

Trigger B.G. 1984: Alternative archaeologies: nationalist, colonialist, imperialist, Man 19, 355-70.

Trigger B.G. 1989: A History of Archaeological Thought (Cambridge).

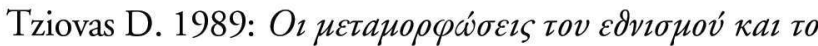

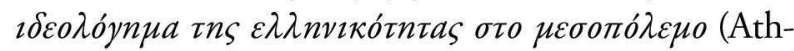
ens).

Valavanis P. 2007: Introduction, in: Valavanis P. (ed.), Great Moments in Greek Archaeology (Athens) 13-15.

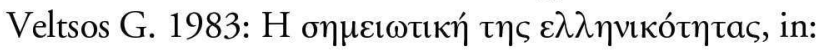

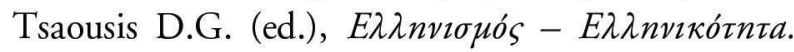

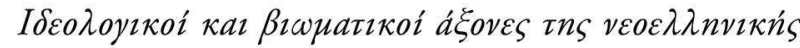
кovvavias (Athens) 225-33.

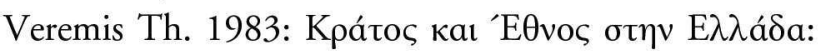

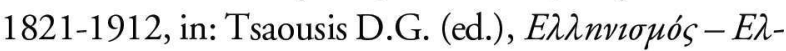

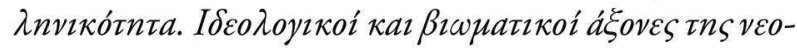
$\varepsilon \lambda \lambda$ nvinńs кoıvavias (Athens) 59-67.

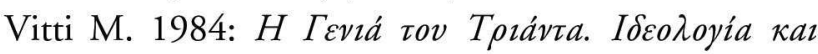
Mopøn' (Athens).

Voutsaki S. 2002: The 'Greekness' of Greek Prehistory: an investigation of the debate 1876-1900, Pharos 10, 105-22.

Voutsaki S. 2003: Archaeology and the construction of the past in 19th century Greece, in: Hokwerda H. (ed.), Constructions of Greek Past: Identity and Historical Consciousness from Antiquity to the Present (Groningen) 231-55. 
PART I.

ANTIQUITY AND

THE GREEK

ANTIQUITIES 
